\title{
Grass Roots: African Origins of an American Art
}

Dale Rosengarten, Theodore Rosengarten, and Enid Schildkrout, eds. 2008. Museum for African Art, New York. Distributed by University of Washington Press, Seattle. Pp. 269, copiously illustrated in black-and-white and color. ISBN (cloth) 978-0-945802-50-1, (paper) 978-0-945802-51-8.

\author{
Reviewed by E. N. Anderson ${ }^{1}$ \\ Reviewer Address: ${ }^{1}$ Department of Anthropology, University of California, Riverside, Riverside, California 92521
}

Received: November $28^{\text {th }} 2009$

Published: August $3^{\text {rd }} 2010$

Many readers of the Journal of Ethnobiology and Ethnobiology Letters will remember the Society for Economic Botany meetings in Charleston in 2009, and the wonderful Sea Island baskets and basketmakers we saw and met there. By happy coincidence, these have finally received proper attention, in the form of an exhibit based at New York's Museum of African Art and currently traveling to several museums around the country (I saw it at UCLA's Fowler Museum of Ethnic Art).

Ordinarily an art exhibit catalogue would not be reviewed in this journal, but the present work is a major contribution to ethnobiology and deserves attention. It traces the roots of the seagrass baskets of the Sea Islands of South Carolina to Africa, primarily West Africa. This is done through eleven major essays (ten chapters and an introduction) by experts in AfricanAmerican history, arts, folklore, and ethnobotany. A great deal of original research was done for this exhibit, and it showed an even more complex and rich African heritage than what had already emerged from research over the past decades. The slaves imported from Africa in the $17^{\text {th }}, 18^{\text {th }}$ and $19^{\text {th }}$ centuries brought a great deal with them-some actual material culture, but much more in the way of knowledge and technique. Judith Carney, who has an essay in this volume, has been the major tracer of ethnobotanical connections, especially in rice (see her now classic Black Rice, 2001, and my review of it in the Journal of Ethnobiology, 2002, as well as her article in that journal, 2003). Anglo-American planters wanted to grow rice, but did not know how; they imported slaves from the parts of West Africa where native rice, Oryza glaberrima, was domesticated and grown. The plantations grew Asian rice (O. sativa), but $O$. glaberrima is still found in a few places in Latin America, having been brought over by the slavessometimes concealed in their hair (Carney 2004).
Volume 1:7-8

(c) 2010 Society of Ethnobiology
The basket technology was used in rice processing, as well as in almost all other walks of life, from divination to carrying children. Baskets were and are made of tough native saltmarsh grasses and rushes. (The one deficiency of this catalogue is a lack of full discussion of species involved; genera include Mublenbergia and Juncus. Pine needles, palm fronds, and other materials are sometimes pressed into service.) As is usual in today's world, there is pressure on the resource base, more from development of all kinds than from collecting.

The great African-American linguistic anthropologist Lorenzo Dow Turner long ago showed that many African words, largely but not entirely from the Wolof and Mende languages, survived in the Gullah dialect. (Many also survive in Louisiana and elsewhere.) In the Sea Islands he recorded a Mende song (Turner 2002:256), which has later crossed and recrossed the Atlantic several times and been re-recorded in later versions-it is still current.

Teasing out the full complexity of the sources of baskets is difficult, but it appears that not only the ricegrowing areas of West Africa, but all of the West African slave source areas from the Gambia to Angola, were involved in basket history and in the formation of the Gullah (or Geechee) ethnic group on the Sea Islands. J. Lorand Matory, in Chapter 10 herein, points out that the Gullah were not so isolated as usually claimed, and that their ethnicity was formed through interaction with black, white, and Native American groups, all quite diverse. He thus feels optimistic for its future; fears that contact with the outside world would destroy it have turned out to be overdone. There is, in fact, something of a cultural renaissance and reaffirmation today, as we could see at the 2009 Economic Botany conference. 
This book shows what can be done with ethnobotany applied to the study of arts and crafts. The survival of Gullah culture in the face of centuries of slavery, racism and oppression is astonishing. Mere survival would have been a major achievement of the human spirit, but African-Americans have done more: they have created superb art and culture under appalling circumstances. Even the slaveowners had to admit this, however grudgingly, but now it is getting its full due.

\section{References Cited}

Anderson, E. N. 2002. Black Rice, by Judith A. Carney. Journal of Ethnobiology 21:53-54.

Carney, Judith A. 2001. Black Rice. Harvard University Press, Cambridge.

-. 2003. African Traditional Plant Knowledge in the Circum-Caribbean Region. Journal of Ethnobiology

23:167-186.

- 2004. With Grains in Her Hair: Rice in Colonial Brazil. Slavery and Abolition 25:1-27.

Turner, Lorenzo Dow. 2002 (orig. 1949). Africanisms in the Gullah Dialect. University of South Carolina Press, Columbia. 